\title{
A Malaysia of Citizens: Ethnicity, Membership and Politics of Merger
}

\author{
LOW CHOO CHIN \\ History Section, School of Distance Education \\ Universiti Sains Malaysia, 11800 USM Pulau Pinang, Malaysia \\ lowc@usm.my
}

Published online: 15 September 2017

To cite this article: Low, C.C. 2017. A Malaysia of citizens: Ethnicity, membership and politics of merger. KEMANUSIAAN the Asian Journal of Humanities 24(2): 1-30, https://oi.org/10.21315/ kajh2017.24.2.1

To link to this article: https://doi.org/10.21315/kajh2017.24.2.1

\begin{abstract}
This paper examines the political history of the relationship between Malaysia and Singapore, focusing on the notion of citizenship and its ethnic, civic and political dimensions. It analyses the extent to which the merger of Singapore with Malaysia redefined the citizenship boundaries of the Malaysian national political identity. The incorporation of Singaporean citizens into the Malaysian political community was controversial, as it was closely related to electoral stakes. The ruling People's Action Party and the Alliance Party attempted to delineate the political sphere of the population of each political unit through the demarcation between 'citizenship' and 'nationality'. However, the citizenship crisis continued to trouble the relationship of these states to the point that both parties breached the perceived agreement not to interfere with the other's political sphere of influence. This sphere of influence was delineated on the basis of race, thus cutting across political territory rather than territorial attributes. The ideological clashes over the meaning of citizenship that arose during the political merger of Singapore and Malaya, show that a truly Malaysian citizenship could not be developed - only a Malaysia of citizens.
\end{abstract}

Keywords and phrases: citizenship, ethnicity, political merger, extraterritorial electoral participation, Singapore

\section{Introduction}

Singapore's merger shows the dissonance between the definition of citizenship and the construction of identity. There is a growing discrepancy between Malayan officials' construction of citizenship and Singapore's perception of belonging; this duality of membership definitions ignited the merger - and separation - conflicts. This paper contextualises the tension between citizenship, state and nation within the institutionalist framework, and propose that the merger was further complicated

(C) Penerbit Universiti Sains Malaysia, 2017. This work is licensed under the terms of the Creative Commons Attribution (CC BY) (http://creativecommons.org/licenses/by/4.0/). 
by competing views on citizenship. The difference between Singapore's and the Federation's understanding of citizenship provided the grounds to contest citizenship.

Citizenship is a frontier of sorts, defining political membership in a nationstate. The question of citizenship was "one of the thorniest issues" that troubled Singapore's Prime Minister, Lee Kuan Yew during Singapore's merger with Malaya to form the Federation of Malaysia (Tan 2008, 93). The citizenship issue relating to Singapore's merger was caused by restrictions on the political activities of Singaporean citizens on the island. To achieve this aim, the two states carefully drafted the 1961 Singapore White Paper, which resulted in granting Malaysian 'nationality without citizenship' to the citizens of Singapore. The Singapore White Paper provided a common nationality, but proposed the creation of "differentiated citizenship" (Tan 2008, 94). Integrating the territories of Malaya and Singapore without uniting their citizens under a common Malaysian citizenship challenged the very notion of belonging in the new federation (Tan 2008, 116). The Malaysian case illustrated the "tensions between the idea of citizenship as an expressive affiliation and citizenship as a form of political equality [or legal status]" (Jackson 2001, 129).

Though drafters of the White Paper did not intend to create inequality among the citizens of Singapore, the merger deal between Malaya's Prime Minister, Tunku Abdul Rahman (Tunku) and Lee Kuan Yew created pre-merger havoc. The restriction of political activities was institutionalised in the 1963 Malaysia Agreement. In devising a constitutional method to differentiate the political rights of the citizens of Singapore, the writers of the 1963 Malaysia Agreement developed the distinction between "a Singapore citizen" and "a citizen who is not a Singapore citizen" in the citizenship provisions of the Malaysian constitution (Tan 2008; Lau 1998; Hill and Lian 1995). The exclusion of Singaporean citizens from Malaysian citizenship raises three important questions. First, what is the relationship between the state and nation, and why is this distinction important in light of what happened in Singapore and Malaysia? Second, what can be learned about the relationship between race, state and nationality? Third, what are some of the particularities of the case between Singapore and Malaysia regarding the generalised relationship between citizenship and nationality?

\section{Literature Review}

Wee suggested that the merger was unworkable from the very beginning, a reality he characterised as "divorce before marriage" $(2001,546)$. A merger motivated by a "mixture of economic and political necessity or expedience" defies the point 
of a merger $(2001,546)$. Singapore tied the so-called marriage knot to ensure its economic survival and to deal with a communist threat. The Federation had been hesitant to accept the British 'marriage proposal' and was unconvinced that the containment of communism justified the inclusion of Singapore's Chinese voters. The ethnic question was thought to be solved by bringing Sabah and Sarawak into the new Federation; however, it remained problematic. The merger continued to be troubled with race relations and the question of whether the Federation should be a multiracial state or a Malay-dominated state (Wee 2001, 546).

Jones demonstrated that ethnic consideration was the main imperative behind the merger principle. In 1962, Tunku rejected the British idea of an early merger with Singapore before the incorporation of the Borneo territories, despite the British concern that Singapore security and Lee's position might deteriorate (2000, 96). The Chinese Singaporean population was deemed culturally unassimilated and politically inequitable. Tunku believed excluding this population from the national franchise would prevent racial polarisation; to him, responsible voting was an issue because the Federation had to bear the consequences of the electoral outcome (Jones 2000). To contain the political influence of Singapore's electorate, the Singapore population was distinguished from the other citizens of Malaysia. Jayakumar and Trindade coined 'citizenship dichotomy' to refer to the two classes of Malaysian citizens: "citizens who are Singapore citizens" and "citizens who are not Singapore citizens". The dichotomy has legal consequences in terms of the right to vote and to stand for election to the legislature (1964, xlviii).

Lau (1998, 2009), Tan (2008) and Hill and Lian (1995) have thoroughly examined the subject of citizenship in Singapore's merger with Malaysia. Written with the benefit of access to previously closed archival sources, the authors provided useful insights on the subject. Lau showed that the reason for Singapore's separation was the breaching of the unwritten constitutional terms that Singapore and the Federation had previously accepted $(1998,286)$. Both Tunku and Lee were convinced that the agreement existed due to not having taken part in the elections in each other's territory. Lee had assured Tunku that the People's Action Party (PAP) of Singapore would not be involved in the federal elections, while Tunku had given a similar assurance of not participating in the Singapore state elections. The decision of the Alliance Party and the PAP to contest each other's elections was a mistake, triggering a chain of events. Both regarded it as a breach of their perceived agreement of non-intervention in each other's political spheres of influence (Lau 1998, 287). 
Lau referred to Tunku and Lee's agreement "not to take part in elections in each other's territory" as a "gentleman's agreement" (2009, 107). Tunku believed that the PAP breached the 'unwritten citizenship term':

\begin{abstract}
When Singapore came into this new nation of Malaysia, we had agreed under the constitution that she should have representation in our parliament and fit into the pattern by having her own administrative machinery, and her own elections. The first sign of Singapore's attempt to have a hand in the affairs of Malaysia was in the last elections when the PAP contested some of the constituencies. This was quite contrary to what we agreed. (Straits Times 21 September 1964)
\end{abstract}

Tunku's speech above invites us to rethink the relationship between extra-territorial electoral participation and the separation of Singapore. According to Tunku's understanding, there was an agreement between Kuala Lumpur and Singapore that restricted the influence of each political unit in the other's territory. Political scientist, R.S. Milne argued that "there had actually been an understanding ... that the PAP would keep out of politics in Malaya" $(1966,179)$. Milne stated that Malaysia's Prime Minister, Tunku Abdul Rahman, was "convinced that such an agreement existed and believed that the PAP had broken it" $(1966,180)$. The reasons for Singapore's separation from Malaysia are diverse, but this paper identifies the occasion that links to the breach of the unwritten agreement between Tunku and Lee Kuan Yew on their respectively not contesting in each other's political domain.

Hill and Lian looked at the relationship between nation building and citizenship in Singapore, and they argued that the competing conceptions of citizenship complicated the merger. The Singapore Citizenship Ordinance of 1957 was extremely liberal and inclusive based on jus soli and equal rights for all citizens, as compared to the exclusive understanding of the 1957 Constitution of the Federation of Malaya $(1995,40)$. The Malaysia Agreement of 1963 was defined as: "a compromise between two competing states rather than an attempt of unification". (Hill and Lian 1995, 59). At the outset, both sides had dissimilar views of what constituted the new nation's political identity; the PAP campaign of "Malaysian Malaysia" brought the dormant issue of the natives' racial supremacy into the forefront of political debates, creating Malay nationalism versus multiracialism (Hill and Lian 1995, 60).

In "The Politics of Becoming 'Malaysian' and 'Singaporean", Albert Lau (2009) analysed the divergent conceptions between the PAP and the Alliance Party of what constituted the Malaysian nation - a Malay Malaysia or a Malaysian Malaysia. According to Lau, the politics of separation "reflected the legacy 
of ethnic suspicion and political rivalry" $(2009,104)$. Both Singapore and the Federation had experienced different 'ideological transformations' in the post-war constitutional development. Prior to the merger, both former British colonies had pursued divergent approaches for their nationhood and citizenship. The citizenship issue was closely related to the notion of nationhood. The Federation's nationhood was based on Malay hegemony, and the Alliance viewed the Malaysia project as an "extension of the Old Malaya" based on affirmative citizenship rights for the sons of the soil (Lau 2009, 104). Singapore's version of Malaysia was totally different and was based on an egalitarian concept of citizenship and a Malaysian Malaysia. The PAP was a left-wing and non-communal party, in contrast with the rightwing and communally orientated Alliance Party (Lau 2009, 105). The citizenship debates in the new Federation of Malaysia were an extension of the communal issue that brought up the dormant question regarding Malay hegemony.

In Creating 'Greater Malaysia': Decolonization and the Politics of Merger, Tan Tai Yong devoted one chapter to discuss the citizenship issue. Tan examined how Lee and Tunku reached a consensus of the new constitutional arrangement and argued that the citizenship provisions were "the most severe and politically damaging criticisms" among the terms of the Singapore White Paper proposals (2008, 92). The last-minute change in the White Paper's citizenship deal resulted in the PAP's success in the 1962 Singapore merger referendum, thus ending the "battle for merger" $(2008,93)$.

The former Prime Minister of Singapore, Lee Kuan Yew, and the former Malaysian Foreign Minister, Ghazali Shafie, have discussed the complexity of the citizenship questions in their published memoirs. In his memoir, The Singapore Story, Lee (1998) admitted that the citizenship question was his main merger issue. Without the status of federal citizenship, Singaporeans would be second-class citizens in Malaysia. The Federation was described as "taking on three wives in Borneo, while Singapore was not to be a fourth wife, but only a mistress. The children of the mistress were going to be treated as illegitimate with no right to federal citizenship" (Lee 1998, 407).

The turning point occurred when Lee timely convinced Tunku prior to Singapore's referendum to change the nomenclature to allow Singaporeans to become 'citizens' instead of 'nationals' of Malaysia (Lee 1998, 438). This last-minute agreement sealed the referendum as a huge success for Singapore's governing party, with 70 per cent voting for the government's merger formula (Lee 1998, 451), ending the citizenship controversy. Ghazali Shafie's memoir on Malaysia's formation acknowledged that the Singapore White Paper sought to differentiate between Singapore citizens and federal citizens: 
As I understood it, what was agreed in Kuala Lumpur was that those born in Singapore should not enjoy the same citizenship rights as those born in the Federation; any change in the citizenship law of Singapore would have to receive the concurrence of the Central Government. (Shafie 1998, 262)

This paper extends the existing literature by analysing how the competing models of citizenship were reinforced by the merger politics. Expansion of political activities across the causeway reflected the political aspiration of the leaders to export their own citizenship model into the territory of the other, thereby violating their agreement of citizenship. The infringement of the citizenship arrangement between Kuala Lumpur and Singapore constituted one of the reasons of Singapore's separation in 1965. This paper draws upon primary materials, official historical records, correspondences between state leaders, memoirs, parliamentary records of both the Singapore Legislative Assembly and the Federation of Malaya, a published collection of British archival sources, online newspapers and secondary publications.

\section{Theorising Citizenship, Consociationalism and Institutionalism}

Citizenship evolved in France, America and England as a result of the key revolutionary events - the French Revolution, the American War of Independence and the English Civil War, respectively (Isin and Turner 2007, 5). Citizenship rights in Asian countries, on the other hand, were developed from anticolonial movements, peasant struggles and working-class movements. Political and civil rights in Malaysia, according to Verma, "have been associated with and developed by the constitution and became identified with state power" $(2002,57)$. The Malaysian concept of citizenship is very particular. It differentiates between citizenship (kerakyatan) and nationality (kewarganegaraan) and provides a nonegalitarian understanding of citizenship.

In Malaysia, nation membership and state membership are not closely integrated. State membership existed prior to national membership; in the early 19th century, the Malay States played a central role in developing their state citizenship as distinct from Malayan nationality. With the formation of the Federation of Malaya in 1948, a national citizenship was created for all of Malaya. Malayan citizenship was lacking a national characteristic because the nation state in itself was incomplete, and so Malayan citizenship was only associated with state nationality after 1952 . The 1952 State Nationality Enactment reinforced the central role of the Malay states in attributing state citizenship, and subsequently national membership. Under the concept of tiered or nested citizenship, nationals of a Malay or British 
sovereign ruler became automatic Malayan citizens. However, state nationality lost its significance after Malayan independence in 1957 (Fransman 1998, 693; Ratnam 1965, 86; Carnell 1952, 515). The merger of Singapore witnessed the revival of the importance of state citizenship; in other words, the distinction between nationality and citizenship emerged from the political usage of Malayan citizenship during the merger.

Although citizenship and nationality both refer to 'the legal quality of statemembership', citizenship reflects the mode of participation while nationality is described by cultural characteristics. In French and English vocabulary, the overlapping usage of these terms shows that the concepts of state, nation and sovereignty are intertwined (Brubaker 1992, 50). Throughout the history of the Federation of Malaya, state membership and nation membership have been used to denote different categories of membership. At the outset, it is important to point out that the state and the nation within the bigger Federation is incongruent. The incongruence between polis and demos creates problems for democratic consolidation (Linz and Stepan 1996, 26).

Communal politics under the operation of an elitist political structure, known as the elite accommodation system, strengthened the legal definition of citizenship. As Freedman noted, "Malaysian politics is highly ethnicised" (2000, 49). Communal politics in Malaya arose from both a British attempt to consolidate its Malayan territories and the debacle that followed the Malayan Union (1946-1948). The emergence and dominance of communally-based political parties in Malaya was not a certainty at this time; it was only with the reservation of special privileges for Malay rulers and the rise of the UMNO that affirmative policies became embedded in the 1957 Federal Constitution (Means 1976). Citizenship was a highly contested area of ethnic compromise in the 1957 Constitution. The elite accommodation system, represented by the Alliance, was made up of communal parties - the United Malay National Organization (UMNO), Malayan Chinese Association (MCA) and Malayan Indian Congress (MIC) - that advanced the interests of the communities they represented (Freedman 2000, 56). Under the bargaining agreement the member parties entered, Malay citizens, as the sons of the soil, were guaranteed special rights, while non-Malay citizens were granted automatic citizenship based on unconditional jus soli. This liberalisation of citizenship law was agreed upon by UMNO politicians in return for the agreement of MCA and MIC politicians to institutionalise the special privileges of the sons of the soil (Means 1976; Verma 2002, 61).

The highly institutionalised citizenship norm became an uneasy accommodation when the Federation was to expand. Racial polarisation extended onto the island 
when the merger took place. In the larger Malaysian Federation, the competing forces of nationalism existed in constitutional tension between ethnic Malay nationalism versus multi-ethnic Malaysian nationalism (Wee 2001, 546). As discussed by Freedman, the elitist accommodation system, or "consociationalism", was the emblem of the Malayan political system in which leaders of a communal party advanced the interests of each ethnic group $(2000,56)$. Under consociationalism, each ethnic group "unified behind leaders who are positioned to bargain for their interests" (Freedman 2000, 56). The term "consociational democracy" was coined by Lijphart to refer to a "government by elite cartel designed to turn a democracy with a fragmented political culture into a stable democracy" (1969, 216). To accomplish this, the elites found a common platform and accommodated the divergent interests and demands of the competing subcultures (Lijphart 1969).

The consociational nature of the Alliance Party differs from Lijphart's model. Political scientist, Diane Mauzy defined consociation practices in Malaysia primarily as "a conflict-management strategy" where democracy plays an insignificant role and political power is unequally distributed among the segments $(1978,144)$. The persistent functioning of the consociational model in the state was supported by a number of favourable societal conditions. First, the Alliance Party had overarching elite cooperation within the context of the ethnically-divided society, in which elite accommodation naturally takes its course. Second, the party portrayed a moderate, rather than a radical, political outlook, which committed to maintaining the British political system. Third, the party was willing to compromise and to accommodate ethnic claims among the leaders of the Alliance in order to reach a consensus; this reflects the sharing of government power among the ethnic components in order to reach an agreement. Fourth, the Alliance Party strategically established a deal, or "rules of the game", that included ensuring representation of major ethnic groups in government and depoliticising sensitive issues by finding common ground among the elite (Mauzy 1978, 145-148).

Elitist deals are constitutionally institutionalised. Malayan citizenship is institutionalised, and its institutionalised norm was empowered by the elitist political structure of the Federation. The institutionalist framework to analysing the Federation's attitude toward a common nationality is guided by the cultural norms and rules of the actors - states, organisations and individuals (Finnemore 1996, 326). The very definition of Malayan membership differs from other Asian countries. Authors writing about this subject find it important to introduce the distinct features of formal state membership before conducting any analysis of Malayan citizenship. Verma reminds us that a complete understanding of legal Malaysian citizenship must consider the absence of egalitarian membership (2002, 80-81). The liberal theories of citizenship are not applicable in an Asian setting, 
specifically in the Malaysian case (Verma 2002, 56). Hill and Lian remind us that Federation law is rooted in the 1948 Federation of Malaya Agreement, which served to preserve the "Malayness" of the state and to limit citizenship to nonMalays through the principle of double jus soli $(1995,58)$. In a move towards selfgovernment, Malayan citizenry was expanded in 1952. The elitist understanding of nationality was based on assimilation to the Federation's way of life; subsequently, state nationality was attributed to the principle of delayed jus soli (Ratnam 1965, 89).

Liberal theories of citizenship were considered inappropriate for all countries, but "different formulations of citizenship could evolve under different circumstances of political and social modernisation in societies like contemporary Malaysia" (Verma 2002, 56). Singapore's merger witnessed the most serious challenge to legal citizenship in Malaya, which was later overcome by severing ties with Singapore (Verma 2002, 61). Having discussed a brief narrative of Malayan citizenship development, the following section will examine why the Malayan case raises questions about nationality within the politics of the merger. The institutionalised norm, combined with the elitist political structure, explains the failure to develop a common Malaysian citizenship and the relevance of a separate citizenship for Singaporean citizens.

\section{Framing the Debates: Citizenship and the Politics of Merger}

Federalism as a constitutional structure is an important consideration when determining citizenship. In a federal nation, citizenship is a place of contest between who belongs and who does not belong (Jackson 2001, 127-128). Citizenship reflects "an agreed relationship in the same territory between different levels of governments that contemplates direct relations between the national government and the people of the subnational governments" (Jackson 2001, 130). A merger requires a new definition of citizenship and a redefinition of the demos. The notion of citizenship is tied to the state; citizens are formed through the creation, unification, division, partition and succession of new states. Membership in a state changes when the state alters its territorial base (Oommen 1997, 227).

During the formation of Malaysia, one of the most complex issues at hand was how to oblige a population with a different citizenship status in the new Federation. As they considered the distinct citizenship laws operating in the four states, the Malayan government was troubled by their diverse racial backgrounds and constitutional development. The populations of North Borneo, Sarawak, Singapore and the Federation of Malaya were all governed by different citizenship laws (Federation of Malaya 1962a, Cobbold Commission, paragraph 27). In 
contrast with the Federation of Malaya Constitution, which provided affirmative rights only for Malays, the Singaporean Citizenship Ordinance granted the same rights for all citizens regardless of their racial origin. The differences between the two states would cause considerable legal problems if Singapore were to join the Federation on the same terms as the other states. Both governments recognised this conflict (Sadka 1962, 18).

Despite the merger, Singapore and the Federation of Malaya maintained their own distinct models of citizenship, which may have undermined the federal structure of governance. In August 1961, Tunku Abdul Rahman and Lee Kuan Yew reached an agreement for a merger. Considering the existing position of Singapore, both states agreed that Singapore would retain its autonomy in education and labour policy. The special rights for the Malays would not be extended into Singapore, and thus the predominantly Chinese state retained its principle of impartiality of citizenship. In addition, Singapore's state citizenship would still qualify citizens for educational and social welfare benefits and entry into the civil service. The agreement protected the Singaporean status quo, but resulted in a special merger arrangement that differed from the other participating states (Sadka 1962, 24).

Under the so-called "Ulster Model", both Tunku and Lee agreed that the Federation would control defence, external affairs and internal security, while Singapore would keep control of education and labour. Singapore was given 15 seats in the House of Representatives, instead of the 25 it was entitled to due to its population. Singapore citizens would be granted only Malaysian nationality instead of Malaysian citizenship. The British had originally suggested this scheme to Lee Kuan Yew. The purpose, according to the British, was to ensure that 'the Federation should have complete constitutional safeguards against any possibility of the Singapore Chinese upsetting the political dominance of the Malays in the Kuala Lumpur House of Representatives (Stockwell 2004, see document 131 dated July 1962, 365). For this special arrangement to work, Borneo could not be offered a better entry term into Malaysia. A greater measure of state autonomy, to be enjoyed by Singapore under the Ulster Model, would not be introduced in Borneo. Tunku and his cabinet opposed the British proposal, which allowed Borneo to retain legislative and executive authority in federal matters after the merger. If Borneo were to enjoy equal state power with Singapore, the special arrangement for Singapore would be "utterly indefensible" (Stockwell, 2004, see document 111 dated 13 June 1962, 309).

This paper suggests that the White Paper merger can be interpreted as formalising a local citizenship for Singaporeans. Singaporean citizenship can be equated to a local citizenship in which Singaporean authorities allocate citizenship based 
on their own criteria. The dominance of state citizenship was spelled out in the "Memorandum Setting Out Heads of Agreement for a Merger between the Federation of Malaya and Singapore" (Command 33 of 1961):

\begin{abstract}
Singapore citizens will continue to enjoy their State rights and privileges within Singapore. Singapore citizens will vote in Singapore for their representatives to the new Federation Parliament and the citizens of the present Federation of Malaya will vote in the present Federation for their representatives to the same new federation Parliament.
\end{abstract}

A separate citizenship is necessary for several reasons. First, citizenship issues were particularly salient because they were related to electoral risks. The political stakes for the Federation were high due to the unique composition of the Singaporean electorate. Tunku felt that the Singaporean Chinese could not be assimilated into the Federation as they "were incapable of adopting a truly Malayan viewpoint" (Jones 2000, 89). What convinced the Tunku's administration to take on the Chinese state was the perceived security threat from a communist government if the PAP lost its state power to the Socialist Front (Jones 2000, 89).

The main factor in the citizenship deal is demography, which is closely connected to the ethicised nature of Singapore's electorate. Both leaders were fearful of the "political repercussions in the mainland of giving the vote to an additional one million Chinese" (Tan 2008, 93). According to Milne (1966, 179), "the Singapore electorate was more dynamic and radical". Without the entry of the Borneo territories, the inclusion of the predominantly Chinese state would bring more non-Malay electors into the newly formed federation. The indigenous population of the Borneo territories was expected to balance the electorate on the side of the Malays. The PAP was ideologically aggressive while the main opposition party, the Socialist Front, was left-wing orientated. To Milne, race was the most important consideration in the restriction of the political role of Singapore in the new Federation $(1966,179)$.

Second, there was "historical variation" (Howard 2006) in the citizenship policies of both states. The Straits Settlements comprising Singapore, Malacca and Penang was disbanded in 1946 and Singapore was established as a separate Crown Colony. Malacca and Penang were brought into a new federal entity together with the nine Malay states, was known as the Malayan Union (1946-1948). Singapore had been kept separate from the rest of the Malayan Union in the post-war reorganisation of British territories in Malaya because of the 'Chinese problem'. This explains the incongruity of the two territories being separated in the first place and the emergence of divisive ethnic politics that permeated the negotiations 
over citizenship. Citizenship was a tool used by the Alliance to maintain Malay political dominance. Singapore's more liberal and egalitarian policies threatened this endeavour from the outset (Hill and Lian 1995). These two widely different citizenship models limited the possibilities of convergence. While the Federation was characterised as an exclusivist citizenship regime, Singapore was characterised as a liberal citizenship regime. Singapore's notion of citizenship was "liberal" and "inclusivist" (Hill and Lian 1995, 58).

At its outset, the citizenship conflict was rooted in the conflicting conceptions of citizenship developed in both territories during the post-war period. Singapore citizenship was based on liberal ideas, while the Federation's version lacked an egalitarian understanding of citizenship, as will be discussed below. Citizenship in the Federation of Malaya was institutionalised and remained difficult to change. What happened in Singapore and Malaysia between 1963 and 1965 demonstrated that the state was decoupled from the definition of nation, i.e. citizenship versus nationality. The decoupling of citizenship and nationality raised the overlapping issues of ethnicity and electoral stakes as grounds for exclusion from Malaysian citizenship. The case between Singapore and Malaysia created a special category of 'Malaysian nationals without citizenship' for a person from Singapore.

\section{Politics of Citizenship in Singapore}

In November 1961, the PAP government published the agreed memorandum on the merger as the Singapore White Paper. The PAP government put forward the White Paper agreement to the Singapore Legislative Council; all 624,000 Singapore citizens would retain their existing state citizenship rights that they enjoyed in Singapore and would be granted an additional Malaysian nationality. Citizens of Singapore would automatically become Malaysian nationals while retaining their Singapore citizenship (Lee 1998, 406). The terminology was used merely as a device to facilitate the implementation of the previous agreement and had no connotation of inequality. Nevertheless, the differentiation between kerakyatan and kewarganegaraan (membership to the state versus membership to the nation) meant that a person from Singapore belonged to the Malaysian nation but not the Malaysian state, which generated a gap between full membership and partial membership.

Prior to the merger, Singapore had achieved the status of internal self-government in 1959 and had legislated its own citizenship law in 1957. The introduction of the 1957 Singapore Citizenship Ordinance complicated the merger. Two different opinions emerged on whether local Singapore citizenship should be introduced prior to the merger. On the one hand, the Chinese community in Singapore, as 
represented by the Singapore Chinese Chamber of Commerce (SCCC), wanted to see positive citizenship policies introduced before the merger. They believed it would be difficult to obtain citizenship rights for foreign-born Chinese in the Malay-dominated Federation, so the rights of a foreign-born Chinese without British nationality had to be secured as part of the merger. The SCCC campaigned for Singapore citizenship, which would enable the 220,000 foreign-born Chinese to gain voting rights (Yeo 1973, 149).

This concern for the citizenship of foreign-born residents was shared by other political parties, who opposed the immediate merger. The Singapore Progressive Party (SPP), a dominant political party in Singapore between 1948 and 1953, felt that Singapore must achieve self-governance before merging with the mainland (Yeo and Lau 1991, 124-125). On the other hand, the PAP argued that the question of nationality must be solved within the context of the Federation. Singaporean citizenship could be developed into a nationality once they became part of the common Malayan citizenship (Yeo 1973, 140). Following their electoral victory in the 1955 election, the Labour Front government promoted the idea of a local Singapore citizenship despite the PAP's insistence that the liberal citizenship rules of Singapore would obstruct the future merger (Chan 1984, 138). Under the Singapore Citizenship Ordinance of 1957, all 220,000 foreign-born Chinese became Singaporean citizens (Yeo 1973, 153). This ordinance was the first step toward bringing Singaporean citizens into the Malayan nation, "this Citizenship Bill marks the first step in the process of rationalising who we mean when we say the 'people of Singapore'. The next step in the process of rationalising is who we mean when we say the 'people of Malaya', for we do not want to be just the people of Singapore” (Ahmad bin Ibrahim, Singapore 1957, Hansard, 11 September 1957, 2566).

Lee Kuan Yew stressed how important it was that the Singaporean citizenship law correspond with the Federation law if the merger were to take place:

If we are honest about merger and the building of one nation, when we draw up our citizenship laws, we must see where it is going to dovetail into the Federation citizenship laws because the moment the principle of merger is accepted we have to discuss the conditions for it. ... If we draw up a list of rules making all and sundry citizens of Singapore in a way which the Federation Government will later find obnoxious and unacceptable, we will be placing ourselves in the most difficult position of having to scrap all those who have acquired Singapore citizenship and make them apply anew for Federation citizenship. (Lee Kuan Yew, Singapore 1957, Hansard, 11 September 1957, 2575) 
Taking into consideration the divergent model of their citizenship laws, Tunku asserted a distinction between a local and national polity. Though constitutionally possible, it was not likely that automatic Malaysian citizenship would be granted to Singaporean citizens since the 1957 Singapore Citizenship Ordinance was much more lenient than the citizenship provisions of the 1957 Federal Constitution. For example, Commonwealth citizens, such as those of Indian origins, were allowed to apply for Singapore citizenship after only two years of residence (Singapore 1964, Hansard, 6 December 1961, 1434). Since the Singaporean citizenship law did not correspond to the Citizenship Law of the Federation of Malaya, an alien found it easier to become a Malaysian national through the Singapore law. In this regard, the Singapore citizenship law would need to be standardised with the Federation law after the merger (Singapore 1964, Hansard, 6 December 1961, 1395).

Tunku wanted to exclude Singapore citizens from being able to vote other states into Malaysia since 230,000 of 340,000 Singapore citizens were not born in Singapore and therefore did not qualify to vote in the Federation. The Federation government wanted to prevent them from increasing their representatives as they did not meet the citizenship requirements (Singapore 1964, Hansard, 6 December 1961, 1411). Since not all Singapore citizens were eligible as Malaysian citizens according to the Federation law, two types of citizenship were needed, one to vote in Singapore and one to vote in the Federation. These two categories could vote for the central parliament in their own states (Singapore 1964, Hansard 1964, 27 November 1961, 735). From an official perspective, the rationale for introducing a separate category of citizenship for Singapore was to reconcile the differences in the citizenship rules of Singapore and the Federation after 1957. The PAP government denied the accusation made by the Socialist Front that they were selling the citizenship rights of Singapore citizens (Singapore 1964, Hansard, 1 December 1961, 1413).

The proposal for two types of citizenship was closely related to the type of merger. On 16 October 1961, Tunku obtained agreement from the Federation of Malaya Parliament to form a Federation of Malaysia with the Borneo states joining in as 'equal members', but Singapore joining in as a 'partner'. As a special partner, Singapore was allowed to retain its local autonomy in exchange for Malaysian citizenship. The main 'handicap' with the Malaya-Singapore partnership was that Singapore citizens were not granted Malaysian citizenship (Hanna 1964, 16-17). Singapore would join Malaysia as a partner based "on a footing something like that which exists between the United Kingdom and the Northern Ireland" because a full merger was impossible, whereas the Borneo states would join Malaysia as members since they did not pose the same threat as Singapore. North Borneo and Sarawak were still British colonies and their constitutional developments were extremely slow, which simplified their membership terms (Federation of Malaya 
1962b, House of Representatives, 16 October 1961, 1063-1064). A complete merger would cause some uneasiness among the people of both territories due to the different constitutional advancement in both countries:

\begin{abstract}
I mentioned that all the States in Malaysia would enjoy equal rights and equal status. But because of the special position of Singapore as a city State, to my mind it would be best if Singapore came in on a partnership basis, with local autonomy with powers to determine nearly all matters except defence, external affairs and security, which must be under the control of the Central Government as they are in all countries with a Federal form of Constitution. (Federation of Malaya 1962b, House of Representatives, 16 October 1961, 1062-1063)
\end{abstract}

Some parliamentary members of the Federation rejected the idea of a Singapore 'partnership', considering the citizenship arrangement a form of 'inequality'. Despite the Prime Minister of Singapore reiterating there was no difference in the Malaysian citizenship and Malaysian nationality, some parliamentary members believed otherwise. As far as international law was concerned, Singapore citizens were the same as citizens of the other states in the Federation;: both categories were federal nationals. However, as far as the internal law was concerned, it was not the same; citizenship mattered for fundamental rights within the country. Tunku's suggestion of a partnership might have given Singapore second-class citizenship. Furthermore, a partnership challenged the root concept of federalism: "If we want to have merger, then all the States must come together into the Federation. It must be a full merger" (Lim Kean Siew, Federation of Malaya 1962b, House of Representatives, 16 October 1961, 1627-1628). A complete merger must, in its truest sense, come with equal citizenship, otherwise the whole concept of federalism would be untenable. A parliamentary member, D. R. Seenivasagam, advocated that "there must be complete merger or nothing" (Federation of Malaya 1962b, House of Representatives, 16 October 1961, 1734). There were certain persons that could not be accepted as citizens of the Federation owing to the Federal Constitution's stringent citizenship requirement. However, Article 22 of the Constitution gave discretionary power to the government to grant citizenship in the event of a new territory's admission. The underlying motive for not accepting Singapore citizens as citizens of the Federation was that 70 per cent of the population was Chinese. Separate treatment of citizenship reflected the government's position of accepting the Singapore state but being unwilling to embrace its population. The people of Singapore would be secluded in the island of Singapore and away from the Federation's political life. The Prime Minister's partnership proposal was considered an offer made to an "unwanted child"; Singapore was deemed as 
"likely to give trouble" and therefore undesirable to be included (Federation of Malaya 1962b, House of Representatives, 16 October 1961, 1736).

The Socialist Front, the main opposition party, strongly opposed the PAP merger proposal since it gave second class citizenship to Singapore's population. The party criticised the PAP for giving up civic and political rights of its citizens in return for local autonomy in education and labour. The Socialist Front demanded a full merger with Singapore to become the 12th state of the Federation, allowing its citizens to become automatic Malaysian citizens. They proposed that Singapore join the new Federation as a state, as was the case when the states of Penang and Malacca joined the Federation of Malaya in 1957 (Simandjuntak 1969, 138).

Neither the Singaporean nor Malayan governments accepted the Penang and Malacca approach to the merger. According to Lee Kuan Yew, only 284,000 Singapore-born citizens would automatically become Malaysian citizens if the existing Federation of Malaya citizenship law in Penang and Malacca were applied in Singapore. The remaining 340,000 foreign-born Singapore citizens would be required to apply for Malaysian citizenship in accordance with the Federation law, which required a residency period and a passing mark in the Malay language test. Of these 340,000 Singapore citizens, two-thirds of them would fail to meet the stricter citizenship criteria and lose their existing citizenship. This was the main problem with a full merger (Lee Kuan Yew's letter to Tunku dated 11 November 1961, in Singapore 1964, Hansard, 24 November 1961, 690). Malayan and Singaporean historians do not agree that the differences in constitutional developments in Singapore were the main reason for the proposed agreement, nor do they concur that the citizenship handicap was traded in exchange for Singapore's local autonomy (Milne 1966, 179).

\section{Overcoming the Differences and Breaking the Deadlock}

The citizenship question remained the most complex problem with the merger. The Federation of Malaya was not willing to grant Malaysian citizenship automatically to Singapore citizens and did not recognise Singaporean citizenship as a qualification for Malaysian citizenship. The idea that Malaysian nationals were not the same as Malaysian citizens caused political havoc and paved the way for the Socialist Front to oppose the merger (Lee 1998, 407-408). Separate citizenship rights for Singapore citizens caused the Socialist Front to criticise the whole PAP merger plan:

If the term 'Malaysian national' was the same as 'Malaysian citizenship' as claimed by Lee Kuan Yew, why would the PAP oppose the opposition 
party's suggestion for Malaysian citizenship? If the rights of Singapore citizens were the same as other Malaysian citizens, why would the PAP not grant them Malaysian citizenship? (Singapore 1964, Hansard, 5 December 1961, 1319)

Under the PAP's approach to a merger, Singaporeans could not share a common political life with other citizens. While the citizens of the 11 states in the Federation could participate in political activities in peninsular Malaysia, Singapore citizens could not. Citizens of the 11 states would share a common political right that excluded Singapore citizens (Singapore 1964, Hansard, 30 November 1961, 994-995). The White Paper proposal threatened the principle of a merger, instead of creating a common citizenship, the White Paper presented two classes of citizenship. As a member of the Singapore Legislative Council pointed out: "Merger cannot mean anything else. The present arrangement for separate citizenship ... is in direct contradiction to the concept of merger and, in fact, nullifies it" (Singapore 1964, Hansard, 30 November 1961, 1004). Critics were quick to point out that separate citizenship was not conducive to the creation and the unity of a nation (Singapore 1964, Hansard, 27 November 1961, 739). According to the Socialist Front, if the Federation was sincere in their intent to merge, it was obligated to accept Singapore citizens the same way it accepted citizens of the Borneo states. Tunku seemed to be willing to grant Malaysian citizenship to Borneo citizens (Singapore 1964, Hansard, 20 November 1961, 333-336).

The opposition party did not strictly oppose the citizenship term used by the White Paper, but it was concerned with its implication. The word 'citizenship' was more important for national purposes; the Socialist Front believed citizenship and nationality were two different concepts even though Lee Kuan Yew reiterated that these terms were the same. Malaysian nationality was insignificant since citizenship determined their rights in a country. A member of the Singapore Legislative Council made the following distinction: "'Citizenship' expresses the rights of an individual within a State and 'nationality' his right outside the State" (Singapore 1964, Hansard, 21 November 1961, 357). For this reason, opponents assumed that Singaporean citizens would only enjoy the same rights as other citizens outside of Malaysia and would not enjoy the same rights within the country (Singapore 1964, Hansard, 30 November 1961, 1005). The PAP confused citizens by stating that there were no real differences between Malaysian citizenship and Malaysian nationality. The two concepts, which referred to national rights and international rights respectively, were used by the PAP to refer to the same idea (Singapore 1964, Hansard, 30 November 1961, 1003-1004). 
Although the terms nationality and citizenship are used synonymously to refer to the status of an individual in his/her relationship with a state, these terms are not the same. Citizenship refers to individual rights and duties in the society, while nationality refers to one's international identity. Nationality denotes the individual's international status while citizenship reflects his domestic status (Fransman 1998, 3). Nationality is used for interstate purposes under international law whereas citizenship is used for domestic purposes (Fransman 1998, 4). Weis distinguishes nationality and citizenship as, "Conceptually and linguistically, the terms 'nationality' and 'citizenship' emphasize two different aspects of the same notion, State membership. 'Nationality' stresses the international, 'citizenship' the national, municipal, aspect” (1979, 4-5).

The Prime Minister of Singapore faced many challenges defending his merger deal. Scholars have explained the merger deal as a combination of PAP's internal tensions in 1961 and the deterioration of Lee's position, along with the surge of radical and left-wing factions as evidenced by the defeat of PAP in the Hong Lim and Anson by-elections. Lee, who was faced with losing the general election to the Socialist Front, was determined to achieve 'independence through merger' for Singapore. This was seen as the only way to secure PAP's political dominance, and so Lee stated he would accept "any form of merger" (Jones 2000, 87-88).

\section{The Last-Minute Citizenship Deal, Changes in Nomenclature}

As the Singaporean government held a referendum on the merger, the Cobbold Commission prepared for North Borneo and Sarawak to join Malaysia. In making recommendations for the terms of their entry, the Cobbold Commission needed to consider whether the status of local citizenship for North Borneo and Sarawak should be created prior to joining Malaysia (Federation of Malaya 1962a, paragraph 148). The terms of citizenship would influence the result of the Singapore referendum; in order for the referendum to succeed, the Borneo states could not be offered a better citizenship deal than what was being offered in Singapore. In its memorandum to the Cobbold Commission, the Malaysian Solidarity Consultative Committee (MSCC) proposed that all British subjects in the two states become "citizens of the Federation". The natural inhabitants would enjoy a special position as of the Malays in the Federation and automatically become "founder citizens" (Cobbold Commission 1962, Federation of Malaya 1962a, paragraph 29).

When the terms for the Borneo states were announced during the third meeting of the MSCC, Lee Kuan Yew expected that his difficulty would intensify. The terms used in the proposal showed that the status of citizens was higher than that of nationals. If the recommendation were accepted by the Tunku government, he 
would have had trouble justifying the different treatment between citizens of Borneo states and citizens of Singapore. He did not take the MSCC recommendation under advisement as the discussion was not yet finalised (Lee 1998, 415). When Lee Kuan Yew looked at the final draft of the Cobbold Report, he expressed concern that all those born in the Borneo states would automatically qualify for Malaysian citizenship. The Prime Minister of Singapore exclaimed, "this is a disaster" (Lee 1998, 432). Prior to reviewing the draft, he still believed that Singaporean voters would vote for a separate Singaporean citizenship in order to retain it (Shafie 1998, 233), but the Singapore referendum would fail once the report was published. Before the report was issued, Lee Kuan Yew wrote a letter to Tunku on 12 July 1962 to suggest that Tunku use the same citizenship terms for Borneo and Singapore without changing their original agreement on the restriction of voting rights:

\begin{abstract}
Singapore citizens could become Malaysian citizens without creating any problems, because the Cobbold Commission had also recommended that electoral rights should only be exercised in the territories where the citizens were normally resident. In other words, Borneo citizens would vote in Borneo and Singapore citizens would vote in Singapore, so Tunku need not fear being swamped by Chinese from Singapore casting their ballots in Malaya. (Lee 1998, 432)
\end{abstract}

Since most of the opposition against Singapore's White Paper was grounded on Tunku's refusal to offer the same citizenship terms to Singapore, Lee Kuan Yew believed that the opposition threat could be resolved by offering Singapore the same terms as the Borneo states. Lee even exerted his pressure on the British, urging them to push Tunku to grant equal citizenship rights to Singapore; he would advocate against a merger if his request was not granted. The Socialist Front had already strengthened its position by politicising the fact that citizens of Singapore would be second-class citizens in Malaysia; their discrimination concerns would be dispelled if Tunku agreed to change the term "Malaysian nationals" to "Malaysian citizens" before the referendum took place (Lee 1998, 429).

On his way back from a trip to New York, Lee stopped to meet Tunku in London, who was negotiating the terms of Borneo's entry with the British government. In the presence of the British, Lee Kuan Yew urged Tunku to solve the question of Singapore citizenship as Britain would not be able to intervene on behalf of Singapore after the formation of Malaysia. The British discussed the issue with the Deputy Prime Minister of the Federation of Malaya, Tun Abdul Razak, stressing that the issue needed to be resolved before the British signed any agreement about Borneo (Lee 1998, 436-437). On 30 July 1962, Lee Kuan Yew wrote to Tunku requesting that he formally verify their new concession: 
Some people find it difficult to understand that there is no difference in calling Singapore citizens 'nationals' or 'citizens' of the new Federation of Malaysia. We have, therefore, agreed that, since this question of nomenclature has loomed large in the minds of some sections of the people, paragraph 14 of the white paper should be amended so that citizens of Singapore will be citizens of Malaysia instead of nationals of Malaysia. (Lee 1998, 438)

The next day, Tunku gave Lee Kuan Yew his consent in writing:

I confirm that the arrangement for citizenship of the inhabitants of Singapore will be in the form agreed between the governments of the Federation of Malaya and Singapore set out in paragraph 14 of Singapore White Paper Command 33 of 1961, as amended in regard to nomenclature and franchise in the terms of the statement. (Lee 1998, 438)

On 14 August 1962, Lee Kuan Yew announced the good news:

Common Malaysian citizenship will be given to all Singapore citizens on merger with the Federation next year. This will mean complete equality and parity for all Malayan citizens and the abolition of separate citizenship of the Federation of Malaya. (Straits Times, 15 August 1962)

The Malaysia Agreement, which was signed in London on 9 July 1963, differentiated citizens of Singapore by making a distinction between "a Singapore citizen" and "a citizen who is not a Singapore citizen" in its citizenship provisions (Malaysia Agreement, Federation of Malaya 1963b, 20-26). This categorisation was understandable; Tunku and Lee Kuan Yew only agreed to change the nomenclature from Malaysian nationality to Malaysian citizenship for citizens of Singapore to maintain differences in their political rights. The next day, Tunku made a similar announcement. According to Tunku, all citizens of the Federation, including Singapore citizens, would have similar rights, hold the same passport, be entitled to the same protection and have the same duties and responsibilities. Certain rights, such as voting rights and employment in the state government service, were reserved for the citizens of a particular state (Federation of Malaya 1962c, House of Representatives, 15 August 1962, 1095-1096).

Though a common citizenship was institutionalised under the 1963 Malaysia Agreement, the Socialist Front continued to criticise the existence of two classes of citizenship under the umbrella of a common citizenship, a class of citizens in the 11 states in Peninsular Malaysia, Sabah and Sarawak, and another class of 624,000 citizens of Singapore (Singapore 1963b, Hansard, 30 July 1963, 371- 
372). The party questioned the meaning of a common citizenship if the citizens of the Federation of Malaya, Sabah and Sarawak were categorised as one group while citizens of Singapore were identified as another (Singapore 1963b, Hansard, 30 July 1963, 442). The historian Simandjuntak viewed the agreement between Tunku and Lee as being intended to maintain the status quo, which separated Singapore from other states in Malaysia:

The equality existed in having identical rights and responsibilities under the common label of 'Malaysian citizenship', but Singapore Malaysian citizens would be restricted to Singapore, and the Federation Malaysian citizens to the rest of Malaysia in the exercise of these equal rights and responsibilities. In other words, Singapore citizens would not be able to have a common political life with the citizens of the rest of Malaysia. (Simandjuntak 1969, 190)

Citizenship provisions (Clauses 23 to 34) under the 1963 Malaysia Agreement were unnecessarily complex for one purpose: to distinguish Singapore citizens from other Malaysian citizens (Lim Kean Siew, Federation of Malaya 1963a, House of Representatives, 15 August 1963, 1026). In acquiring federal citizenship, different residential criterion, language qualifications and authorities applied to the persons of Bornean States and Singapore, resulting in many types of citizenship when all the citizens were supposed to be united as one people. The existence of two citizenship classes was inconsistent with the aim of uniting a Malaysian nation-state with a common citizenship, and the Federation's legislative members severely criticised the situation. Different voting rights and citizenship qualifications applied in Federal, Singaporean and Bornean territories caused unnecessary complications in the Malaysian citizenship provisions and failed to unite all citizens under one Malaysian nation (Federation of Malaya 1963a, House of Representatives, 15 August 1963, 1028-1030).

Regarding immigration, citizenship rights varied between the people of Bornean states and non-Bornean states. The rights of entry into Borneo were subject to obtaining a pass. The Bornean states regulated immigration, and the freedom of movement was restricted for non-Bornean residents. Centralisation of citizenship and immigration governance was delegated to the state government. Apart from the existence of multilevel citizenship, there were two different authorities within the nation-state responsible for implementing citizenship provisions involving Singaporeans. The Singapore government determined the acquisition and loss of Singapore state citizenship, which was decisive as a pre-condition for federal citizenship. The Federal government had the right to terminate a Singapore citizen's federal citizenship. The loss of either citizenship would cause the Singapore citizen 
to lose the other citizenship as well, placing Singaporeans under "double jeopardy" (Federation of Malaya 1963a, House of Representatives, 15 August 1963, 10331034). A legislator, Lim Kean Siew, commented that:

There can and there should never be citizens divided into classes. Every person must be equal before the eyes of the law. Yet, we have here the citizenship provisions which not only distinguish ourselves into various classes but also into various categories - Federation of Malaysia citizen (Bornean type), Federation of Malaysia citizen (Singapore type and Malayan type) and so on, as if we are different species of monkies ... It is stated that the Singapore citizenship is the same as the Federation Citizenship. Yet, in spite of what is stated, Singapore citizens are distinguished from the others. (Federation of Malaya 1963a, House of Representatives, 15 August 1963, 1032-1033)

During the debates on the Malaysia Bill, there were opinions that Singapore's position in the new Federation was unfavourable, with only 15 parliamentary seats in the House of Representatives. Citizenship and immigration restrictions were disadvantageous to the Singaporeans. First, residence in Singapore was not considered as fulfilling the residential qualification to become a federal citizen, while residence in Sabah, Sarawak, and the Federation of Malaya were counted. Second, they had no right to enter Borneo territories. Third, they could not stand for election and vote in the Federation of Malaya. In exchange for Singapore autonomy in education and labour, the people of Singapore would not become common citizens of Malaysia (D.R. Seenivasagam, Federation of Malaya 1963a, House of Representatives, 16 August 1963, 1076-1077). Therefore, the Malaysia Agreement created many types of citizenship, each one varying in its duties and obligations. The complexity of the legal citizenship provisions came under heavy scrutiny. Another legislator, V. Veerappen, stated:

We are not trying to unite; we are dividing the people. Citizenship is a complete confusion. What do you understand, by the term 'a Federal citizen who is not a Singapore citizen' when, in another place, it says 'a Singapore citizen is automatically a Federal citizen'? Who can understand? Look at the clumsiness of the phraseology. (Federation of Malaya 1963a, House of Representatives, 17 August 1963, 1164)

In defending the two classes of citizenship, Tun Abdul Razak reiterated that Singapore joined Malaysia on special terms, Singapore already enjoyed the status of internal self-government, and Britain permitted Singapore to maintain its autonomy in the state's internal affairs; "there could not be any inequality since it was merely an arrangement" (Federation of Malaya 1963a, House of 
Representatives, 19 August 1963, 1309). Jayakumar and Trindade argued that "there was some hesitancy in providing that Singapore citizens should acquire citizenship of the proposed new Federation, the fear probably being that this could result in a political disadvantage to Malaya" (1964, xlviii).

The failure to abide by the agreed citizenship terms brought Kuala Lumpur and Singapore relations to a standoff, which eventually paved the way to separation. The Singapore-Malaysia debate on citizenship included normative, empirical and theoretical aspects. The normative facet focused on whether multicultural and liberal citizenship could be introduced in the new Federation. The empirical approach examined how the state determined who could be a full member of their political community and why a separate citizenship was relevant. The theoretical perspective explored the tension between the concept of citizenship as a right and as an identity.

\section{Unwritten Citizenship Terms}

Specific citizenship provisions agreed to by both Kuala Lumpur and Singapore did not prevent UMNO and PAP activists from intervening in each other's elections. In the 21 September 1963 Singapore election, the Tunku's newly founded Singapore Alliance (SA) contested in 42 constituencies. To the Tunku's dismay, the SA, comprised of the Singapore branches of UMNO, MCA, MIC and Lim Yew Hock's Singapore People's Alliance (SPA), did not win any seats. The PAP won 37 seats out of 51 seats, soundly defeating the Socialist Front and the SA. In the predominantly Malay constituencies previously held by UMNO, the PAP's Malay candidates won popular support. Tunku's aspiration to control Singapore through electoral cooperation with the SPA failed (Lee 2008, 240-241).

The expansion of political activities reflected the aspiration of the leaders to export their own political model into other territories. Nationalism and democracy in Singapore followed a line of egalitarianism while the federal government's nation was based on consociationalism democracy. Elements of race, ethnicity and communalism remained central in their model. The SA's participation in the 1963 Singapore general elections and the involvement of the UMNO, MCA and MIC Singapore branches in the 1959 election was interpreted by historian Albert Lau as an attempt to "duplicate the communally-based politics of the Federation on the island" (1998, 95-96). According to Lau, the federal government aspired to revive SA's influence over the Singapore electorate at the next general election; the SA could become a "more attractive alternative" to PAP $(1998,97)$. Lee Kuan Yew regarded Tunku's move as "undue interference in the Singapore election", but Tunku viewed the electoral loss as a betrayal of UMNO by the Singapore 
community (Lee 2008, 241). The PAP victory thwarted the Alliance Party revival in Singapore. In Albert Lau's words, "Not only had the Singapore electorate rejected communally-based political parties, but, especially among Malay voters, it had voted non-communally in favour of the non-communal socialist PAP against the traditional leadership of the UMNO" $(1998,51)$.

The precedent of the Alliance Party's participation in the Singapore election in 1963 opened the gate for the PAP's tit-for-tat participation in the 1964 Federation election. Developments following Singapore's election showed an 'underlying strain in Singapore-Kuala Lumpur relations', which culminated in the PAP central executive committee's February 1964 decision to contest the coming federal election (Lee 2008, 244). Among other regions, Singapore was not represented in Tunku's new Cabinet - which was represented by one leader from Sabah and Sarawak - and had no executive voice at the federal level (Lee 2008, 250). At this point, Lee Kuan Yew assured federal politicians that the PAP did not aim to contest for political power in the Federation. In September 1963, Lee even promised, "We will not take part in the 1964 elections in the Federation" (Lau 1998, 69). However, PAP's chairman, Toh Chin Chye, announced on 1 March 1964 that the PAP would contest the election, effectively undermining Lee's promise (Lau 1998, 91). The argument was that "if the PAP confined itself to operating only in Singapore, the party would gradually fade out and eventually disintegrate" (Lau 1998, 96).

Lee accepted the committee's decision but avoided a direct contest with UMNO. Placing PAP candidates only in MCA's contested constituencies, Lee wished to take over the position of the MCA as a partner for UMNO. Tunku nevertheless viewed Lee's attempt unfavourably (Lee 2008, 251). In the 1964 elections, the PAP contested 9 parliamentary and 15 state assembly seats. The 25 April 1964 election yielded one seat for the PAP out of nine seats. A Singaporean-based political party had now intervened in the politics of the federation, contradicting the agreed citizenship terms of the Singapore White Paper (Parmer 1966, 115). For Turnbull, the PAP decision was an "ill-judged intervention into federal politics [that] arose partly from impatience" to change the status quo $(1989,280)$. Its leaders undermined the inherent communalism of federal politics; in the eyes of the UMNO politicians, Lee Kuan Yew "had broken a pledge to stay clear of federal politics and not mobilise the peninsular Chinese" (Turnbull 1989, 281). Tunku believed that there was a mutual understanding between both governments that the PAP would not intervene in Malayan politics. When the PAP contested the 1964 Malayan elections, the attempt was seen as violating their earlier agreement. However, the PAP did not consider the agreement legally binding since the Alliance Party had already violated it when the party contested the 1963 Singapore election (Milne 1966, 179). 
Lee Kuan Yew admitted that PAP participation in the election brought serious repercussions to the relationship between Kuala Lumpur and Singapore. The main cause of conflict and eventual separation was attributed to a communal-based political arrangement in which UMNO would "maintain total Malay supremacy" (Lee 1998, 547). UMNO ministers wanted the PAP and other non-Malay parties to confine their political activities to Chinese voters only; the Malay voting bloc belonged to UMNO. Though the MCA accepted these terms, the PAP did not. While the PAP politicians were campaigning for non-communal politics among the urban Chinese population in the mainland, the UMNO politicians were eager to apply the communal formula to the Malay population in Singapore (Lee 1998, 548). Each side sought to define its own sphere of influence, which extended into rival territory (Lee 2008, 254).

The electoral loss of UMNO in Singapore's election and the fateful decision of the PAP to participate in the Federation's election brought the issues of race, ethnicity and communal politics to the forefront of political debates, which stirred a series of provocative and racist speeches across the Causeway. UMNO Secretary-General Syed Ja'afar bin Albar sought to "punish the PAP for daring to participate in the federal parliamentary election, and to reclaim Singapore Malays for the UMNO" (Lee 2008, 251-252). Riots erupted in Singapore in July and September 1964, claiming a total of 36 lives (Lee 2008, 253). The launch of the Malaysia Solidarity Convention in May 1965 and the advancement of the "Malaysian Malaysia" campaign were the political spill over of the 1963-1964 intrusions of the PAP and UMNO parties into opposing political spheres. The "Malaysian Malaysia" campaign promoted parliamentary democracy and equal citizenship rights for all Malaysians, thereby challenging the 1957 Constitution of the Federation of Malaya (Milne 1966, 175; Parmer 1966, 115).

Political scientist, Leifer, argued that the citizenship arrangement between both governments failed to insulate Singapore from Malayan politics $(1965,61)$. It was not effective enough to prevent the racial outbreaks from 1963 to 1965. The failure to insulate Singapore through citizenship arrangements forced Tunku to take action, which meant separating Singapore from Malaysia in order to prevent further violence (Milne 1966, 182). According to Milne, "the insulation was not complete" $(1966,179)$. Though the constitution prohibited Singapore citizens from contesting Malayan elections, it did not forbid Singapore-based political parties from contesting elections in Malaya. Malayan political parties were not bound by the constitution from taking part in Singapore's elections (Lau 1998, 96). Less than two years after the formation of Malaysia, Singapore separated and became a sovereign nation-state. Amendments were made to the Malaysian Constitution and 
the citizens of Singapore - who were once Malaysians - reverted to the status of Singaporeans beginning 9 August 1965.

The categorisation of two types of citizenship in one nation-state for the purpose of political participation did not achieve its stated objective; it failed to prevent the ruling party in each territory from participating in the politics of the other's territory (Hill and Lian 1995, 58). The separation of Singapore revealed contradictions within the citizenship model and the inherent differences in nationalist aspirations of both political parties. The aftermath of the merger witnessed political campaigning to promote their own brand of democracy and challenged the established order prior to the merger. A merger was a matter of political expediency for Singapore and of political and economic aggrandizement for the Alliance. The heavy-handedness of the British was present throughout the negotiations as they dangled the carrot of the Borneo territories in front of Tunku. Alliances of such expediency are flawed from the outset since they do not arise out of organic impulses or movements. That the merger was so short-lived is not entirely surprising.

\section{Conclusion}

The merger between Malaya and Singapore raised complex questions about citizenship and belonging. The Singaporean-Federal case is unique in that it suffered from two levels of citizenship disputes. Having solved the dichotomy between different classes of citizenship, the politicians were confronted with a call for a liberal approach to citizenship. The renewed citizenship issue centred on citizenship rights for Malays and non-Malays. Compared to the debates on citizenship terminology, the discussion surrounding equal citizenship rights was more widespread and garnered the support of political parties in the Federation and Borneo territories. As hinted by scholars (Tan 2008; Lau 1998; Hill and Lian 1995; Milne 1966; Leifer 1965), an act of political expediency could have prevented the expansion of political activities into neighbouring territories. However, the insatiable desire of political leaders to export their own citizenship model into the opposing territory would have resulted in the failure of such an act.

Four factors can explain the contestation over citizenship. First, the institutionalised norm precluded the adaptation of the liberal theory of citizenship. Second, the consociational democracy, or elitist accommodation system between UMNO, MCA and MIC, reinforced the domestic norm, making change impossible. Third, citizenship was a politicised issue, which effectively galvanised public opinion for electoral gain. Fourth, the two nations had divergent models of citizenship exclusivism versus inclusivism - in which each perceived the other as constituting a threat to their national political community. The influence of institutional 
structure and communalism in politics was pertinent to the questions of inclusion and exclusion. These four reasons explain the crumbling of the foundation of the Singapore-Malaysia partnership. The inclusion of Singaporeans as Malayan citizens was seen as a challenge to the boundaries of the Malayan political community after much bargaining and compromise between political parties.

Tunku's initial concern that the inclusion of the citizens of Singapore, who were mostly Chinese, would upset the voting weightage of the Federation, was correct. After Singapore joined Malaysia, Tunku's worry became reality. Tunku's wish to block the citizens of Singapore from federal politics through the distinction of nationality and citizenship had its own rationale. The citizenship crisis continued to impact the relationship of the states to a point where both political parties violated the perceived agreement to stay out of each other's political sphere of influence. This sphere of influence, however, was delineated on the basis of racial attributes, thus interfering with political territory rather than territorial characteristics. As demonstrated in the 1963 Singapore election, the Alliance Party spread its political wings among the Malay electorate; by the 1964 federal election, the PAP had expanded its political activities among the urban Chinese electorate. As race was a central issue in Malaysian politics at the time, it is not difficult to understand why containing extra-territorial political participation was not feasible. The periphery of political influence was not clearly established; if it had been, it would only be conducive to the federal structure of governance. A truly Malaysian citizenship could not be developed - only a Malaysia of citizens.

\section{Acknowledgements}

The author wishes to thank the editorial board of KEMANUSIAAN the Asian Journal of Humanities and the anonymous reviewers for their invaluable comments and constructive critiques, without which this paper would not be in its present form. Their valuable insights have helped to strengthen the paper. The research is supported by Research University Grants (1001/PJJAUH/816294) provided by Universiti Sains Malaysia.

\section{References}

Brubaker, R. 1992. Citizenship and nationhood in France and Germany. London: Harvard University Press.

Carnell, F.G. 1952. Malayan citizenship legislation. International and Comparative Law Quarterly 1(4): 504-518, https://doi.org/10.1093/iclqaj/1.Pt4.504

Chan, H.C. 1984. A sensation of independence: A political biography of David Marshall. Singapore: Oxford University Press. 
Fransman, L. 1998. British nationality law. London: Butterworth.

Federation of Malaya. 1962a. Report of the Commission of Enquiry North Borneo and Sarawak (Cobbold Commission). Kuala Lumpur: Government Printer. . 1962b. House of Representatives: Parliamentary debates, Dewan Rakyat Official Report Vol. III Third Session of the First Parliament (October 1961 to January 1962). Kuala Lumpur: Government Printer. . 1962c. House of Representatives: Parliamentary debates, Vol. IV (April 1962 to December 1962). Kuala Lumpur: Government Printer. . 1963a. House of Representatives: Parliamentary debates, Dewan Rakyat Official Report Vol. V Fifth Session of the First Parliament (May 1963 to December 1963). Kuala Lumpur: Government Printer. . 1963b Malaysia: Agreement concluded between the Federation of Malaya, United Kingdom of Great Britain and North Ireland, North Borneo, Sarawak and Singapore. Kuala Lumpur: Government Printer.

Finnemore, M. 1996. Norms, culture, and world politics, insights from sociology's institutionalism. International Organization 50(2): 325-347, https://doi. org/10.1017/S0020818300028587

Freedman, A.L. 2000. Political participation and ethnic minorities: Chinese overseas in Malaysia, Indonesia, and the United States. New York: Routledge.

Hanna, W.A. 1964. The formation of Malaysia: New factor in world politics. New York: American Universities Field Staff.

Hill, M. and Lian, K.F. 1995. The politics of nation building and citizenship in Singapore. London: Routledge, https://doi.org/10.4324/9780203424438

Howard, M.M. 2006. Comparative citizenship: An agenda for cross-national research. Perspectives on Politics 4(3): 443-455, https://doi.org/10.1017/S1537592706060294

Isin, E.F. and Turner, B.S. 2007. Investigating citizenship: An agenda for citizenship studies. Citizenship Studies 11(1): 5-17, https://doi.org/10.1080/13621020601099773

Jackson, V.C. 2001. Citizenship and federalism. In Citizenship today: Global perspectives and practices, eds. T.A. Aleinikoff and D. Klusmeyer, 127-182. Washington: Carnegie Endowment for International Peace.

Jayakumar, S. and Trindade, F.A. 1964. Citizenship in Malaysia. The Malayan Law Journal 30: xlviii-lvii.

Jones, M. 2000. Creating Malaysia, Singapore security, the Borneo territories, and the contours of British policy, 1961-1963. The Journal of Imperial and Commonwealth History 28(2): 85-109, https://doi.org/10.1080/03086530008583091

Lau, A. 1998. A moment of anguish, Singapore in Malaysia and the politics of disengagement. Singapore: Times Academic Press.

. 2009. The politics of becoming 'Malaysian' and 'Singaporean'. In Across the causeway: A multi-dimensional study of Malaysia-Singapore relations, ed. T. Shiraishi, 92-124. Singapore: ISEAS.

Lee, E. 2008. Singapore: The unexpected nation. Singapore: ISEAS.

Lee, K.Y. 1998. The Singapore story: Memoirs of Lee Kuan Yew. Singapore: Times Editions Pte. Ltd.

Leifer, M. 1965. Singapore in Malaysia: The politics of federation. Journal of Southeast Asian History 6(2): 54-70, https://doi.org/10.1017/S0217781100001885 
Linz, J.J. and Stepan, A.C. 1996. Problems of democratic transition and consolidation: Southern Europe, South America, and post-communist Europe. Baltimore: Johns Hopkins University Press.

Lijphart, A. 1969. Consociational democracy. World Politics 21(2): 207-225, https://doi. org/10.2307/2009820

Mauzy, D.K. 1978. Consociationalism and coalition politics in Malaysia. Ph.D. diss. University of British Columbia.

Means, G. 1976. Malaysian politics. London: Hodder and Stoughton.

Milne, R.S. 1966. Singapore's exit from Malaysia: The consequences of ambiguity. Asian Survey 6(3): 75-84, https://doi.org/10.2307/2642221

Oommen, T.K. 1997. Citizenship, nationality and ethnicity: Reconciling competing identities. Cambridge: Polity Press.

Parmer, J.N. 1966. Malaysia 1965: Challenging the terms of 1957. Asian Survey 6(2): 111118, https://doi.org/10.2307/2642106

Ratnam, K.J. 1965. Communalism and the political process in Malaya. Singapore: University of Malaya Press.

Sadka, E. 1962. Singapore and the Federation: Problems of merger. Asian Survey 1(11): 17- 25, https://doi.org/10.2307/3023636

Shafie, M.G. 1998. Ghazali Shafie's memoir on the formation of Malaysia. Bangi: Universiti Kebangsaan Malaysia.

Simandjuntak, B. 1969. Malayan federalism 1945-1963: A study of federal problems in a plural society. Kuala Lumpur: Oxford University Press.

Sopiee, M.N. 1976. From Malayan Union to Singapore separation: Political unification in the Malaysia region 1945-1965. Kuala Lumpur: University of Malaya.

Singapore. 1957. Legislative assembly debates: Official report (Hansard), Vol. 4. Singapore: Government Printer.

. 1960. Legislative assembly debates: Official report (Hansard), Vol. 4 (21 August 1952 to 8 January 1956). Singapore: Government Printer.

. 1963a. Legislative assembly debates: Official report (Hansard), Vol. 20 (5 April 1963). Singapore: Government Printer.

. 1963b. Legislative assembly debates: Official report (Hansard), Vol. 21 (30 July 1963). Singapore: Government Printer.

. 1964. Legislative assembly debates: Official report (Hansard), Vol. 15 (31 October 1961 to 21 December 1961). Singapore: Government Printer.

Stockwell, A.J. (ed.). 2004. Malaysia: British documents on the end of empire. London: The Stationary Office.

Straits Times. 21 September 1964. The Tengku's plea. 15 August 1962. Lee's trump card.

Tan, T.Y. 2008. Creating 'Greater Malaysia': Decolonization and the politics of merger. Singapore: ISEAS.

Turnbull, C.M. 1989. A history of Singapore, 1819-1975. Kuala Lumpur: Oxford University Press.

Verma, V. 2002. Malaysia: State and civil society in transition. London: Lynne Rienner. 
Wee, L. 2001. Divorce before marriage in the Singapore-Malaysia relationship: The invariance principle at work. Discourse \& Society 12(4): 535-549, https://doi. org/10.1177/0957926501012004006

Weis, P. 1979. Nationality and statelessness in international law. Alphen aan den Rijn: Sijthoff \& Noordhoff.

Yeo, K.W. 1973. Political development in Singapore, 1945-55. Singapore: Singapore University Press.

Yeo, K.W. and Lau, A. 1991. From colonialism to independence, 1945-1965. In A history of Singapore, eds. E.C.T. Chew and E. Lee, 117-153. Singapore: Oxford University Press. 